\title{
DIAGNOSA PENYAKIT DIABETTUS MELLITUS PADA MANUSIA DENGAN SISTEM PAKAR
}

\author{
Hani Nurhayati \\ Jurusan Teknik Informatika, Sains dan Teknologi \\ Universitas Islam Negeri (UIN) Maulana Malik Ibrahim Malang
}

\begin{abstract}
Abstrak - Di masa sekarang segala penyakit bertebaran dimana - mana dengan jumlah dan jenis - jenis yang tidak terhitung jumlahnya. Semakin maju pemanfaatan teknologi, semakin banyak timbul penyakit penyakit baru yang lebih ganas. Sebagai makluk ciptaan Allah yang diberikan akal dan pikiran, kita dituntut mempelajari dan memahami berbagai penyakit dan penyebabnya. Salah satu penyakit pada manusia yaitu Dibettus Mellitus. Oleh karena itu perlu dibuat program komputer sistem pakar yang merupakan salah satu aplikasi dari kecerdasan buatan untuk dapat menentukan tipe jenis penyakit Diabetus Mellitus dan pengobatannya berdasarkan aturan (rule) yang ada dalam basis pengetahuan (knowledge base).
\end{abstract}

Kata kunci : Diabetus Mellitus, aturan (rule), basis pengetahuan (knowledgw base)

\section{LATAR BELAKANG MASALAH}

Di masa sekarang segala penyakit bertebaran dimana - mana dengan jumlah dan jenis - jenis yang tidak terhitung jumlahnya. Semakin maju pemanfaatan teknologi, semakin banyak timbul penyakit penyakit baru yang lebih ganas. Sebagai makluk ciptaan Allah yang diberikan akal dan pikiran, kita dituntut mempelajari dan memahami berbagai penyakit dan penyebabnya. Salah satu penyakit pada manusia yaitu Dibettus Mellitus.

Banyak orang tidak menyadari bahwa dirinya terkena gejala penyakit Diabetus Mellitus, dan lebih memprihatinkan bila orang tersebut baru mengetahui dalam kondisi yang sudah parah. Untuk itu mengetahui tanda adanya gejala Diabetus Mellitus harus diketahui oleh pasien.

\section{RUMUSAN MASALAH}

Berdasarkan pada latar belakang permasalahan sebagaimana disebutkan pada pendahuluan maka sebagai perumusan masalahnya adalah :

1. Bagaimana efektifitas Sistem Pakar dalam mendeteksi dini gejala penyakit Diabetus Mellitus.
2. Bagaimana korelasi Sistem Pakar dalam pengembangan keilmuan di Jurusan Teknik Informatika dalam sumbangsihnya pada dunia kedokteran khususnya pada bagian Penyakit dalam.

\section{SISTEM PAKAR}

Sistem Pakar merupakan aplikasi tunggal dari Kecerdasan Buatan (artificial intelligence), bisa disebut juga sistem pakar merupakan pengembangan dari (artificial intelligence). Dengan begitu kecerdasan buatan (artificial intelligence) dapat dikatakan dasar dari sistem pakar. Arti dari kecerdasan itu sendiri ialah pengetahuan (knowledge), suatu pengertian tentang beberapa subyek yang diperoleh melalui pendidikan dan pengalaman. (Suparman,1991)

Definisi dari sistem pakar sebuah program komputer yang dirancang untuk memodelkan kemampuan menyelesaikan masalah seperti layaknya seorang pakar (human expert).

Tujuan dari sebuah sistem pakar adalah untuk mentransfer kepakaran yang dimiliki seorang pakar kedalam komputer, dan kemudian kepada orang lain (nonexpert). 
Aktifitas yang dilakukan untuk memindahkan kepakaran:

1. Knowledge Acquisition (dari pakar atau sumber lainnya)

2. Knowledge Representation (ke dalam komputer)

3. Knowledge Inferencing

4. Knowledge Transfering

\section{DIABETUS MELLITUS}

Diabetes melitus adalah suatu penyakit gangguan kesehatan di mana kadar gula dalam darah seseorang menjadi tinggi karena gula dalam darah tidak dapat digunakan oleh tubuh. Diabetes Mellitus / DM dikenal juga dengan sebutan penyakit gula darah atau kencing manis yang mempunyai jumpah penderita yang cukup banyak di Indonesia juga di seluruh dunia. Pada orang yang sehat karbohidrat dalam makanan yang dimakan akan diubah menjadi glokosa yang akan didistribusikan ke seluruh sel tubuh untuk dijadikan energi dengan bantuan insulin. Pada orang yang menderita kencing manis, glukosa sulit masuk ke dalam sel karena sedikit atau tidak adanya zat insulin dalam tubuh. Akibatnya kadar glukosa dalam darah menjadi tinggi yang nantinya dapat memberikan efek samping yang bersifat negatif atau merugikan.

Kadar gula yang tinggi akan dibuang melalui air seni. Dengan demikian air seni penderita kencing manis akan mengandung gula sehingga sering dilebung atau dikerubuti semut. Selanjutnya orang tersebut akan kekurangan energi / tenaga, mudah lelah, lemas, mudah haus dan lapar, sering kesemutan, sering buang air kecil, gatal-gatal, dan sebagainya. Kandungan atau kadar gula penderita diabetes saat puasa adalah lebih dari $126 \mathrm{mg} / \mathrm{dl}$ dan saat tidak puasa atau normal lebih dari 200 $\mathrm{mg} / \mathrm{dl}$. Pada orang normal kadar gulanya berkisar $60-120 \mathrm{mg} / \mathrm{dl}$.

Penyakit yang akan ditimbulkan oleh penyakit gula darah ini adalah gangguan penglihatan mata, katarak, penyakit jantung, sakit ginjal, impotensi seksual, luka sulit sembuh dan membusuk / gangren, infeksi paru-paru, gangguan pembuluh darah, stroke dan sebagainya. Tidak jarang bagi penderita yang parah bisa amputasi anggota tubuh karena pembusukan. Oleh sebab itu sangat dianjurkan melakukan perawatan yang serius bagi penderita serta melaksanakan / menjalani gaya hidup yang sehat dan baik bagi yang masih sehat maupun yang sudah sakit.

Jenis Diabetes adalah : Diabetes Tipe 1 Anda menghasilkan insulin sama sekali. Diabetes Tipe 2 Anda tidak memproduksi insulin yang cukup, atau insulin tidak berfungsi sebagaimana mestinya. Gestational Diabetes Anda mengembangkan diabetes hanya selama kehamilan Anda.

\section{MODEL PENGEMBANGAN}

Secara umum, model pengembangan Perangkat Lunak Sistem Pakar terdiri dari dua bagian yaitu : perancangan database dan algoritma cerdas. Kemudian kedua komponen tersebut diimplementasikan ke dalam pemrograman PHP untuk diciptakan Suatu Perangkat Lunak Sistem Pakar berbasis Web.

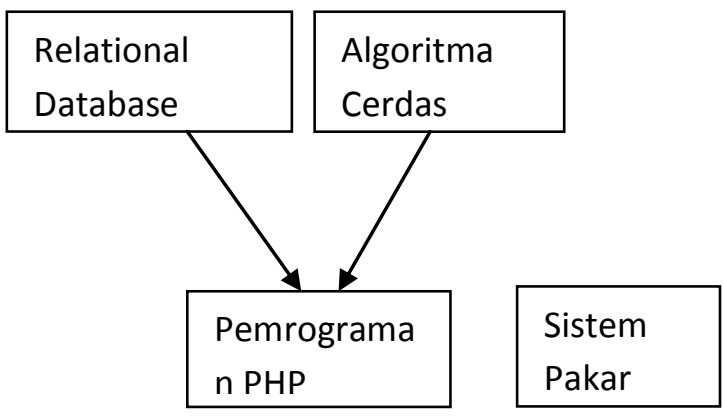

Gambar 1. Model Pengembangan Perangkat Lunak Sistem Pakar

Pada perancangan database dilakukan penyusunan tabel tabel berikut field - field kuncinya yang merupakan relasi penghubung antar tabel. Database ini digunakan sebagai Knowledge Base yang akan digunakan oleh Expert System. 
Knowledge Base yang terpadu dalam Database agar dapat berguna sebagi informasi atau solusi diperlukan AI Algoritma yang berfungsi sebagai Inference Engine yang bertindak sebagai mesin penarik kesimpulan dalam Sistem Pakar.

\section{USE CASE DIAGRAM SISTEM}

Dalam penerapannya, DSS ini akan membutuhkan beberapa element tertentu yang akan mendukung kinerja dari DSS tersebut, diantaranya:

1. Admin

Bertugas membuka dan melakukan maintenance server yang nantinya akan di gunakan oleh pasien untuk berkonsultasi dengan system.

2. User (non-previlagesguest)

User hanya bisa melakukan view website dan melihat beberapa sisi dari website. Untuk mendapatkan hak akses lebih, user dianjurkan melakukan registrasi menjadi member. Dalam hal ini, user masih belum bias melakukan konsultasi dengan system

3. Member (previlagesguest)

Member memiliki hak lebih dari admin sehingga member berhak melakukan konsultasi dengan system. Member juga berhak atas beberapa hal yang berhubungan dengan konten web yang tidak bisa di lakukan oleh user.

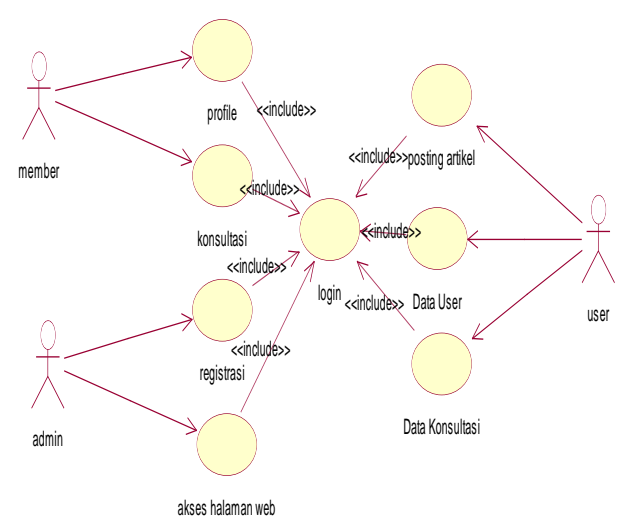

Gambar 3. Desain analisis Sistem Pakar Penyakit Diabetes Militus

\section{ENTITY MODEL}

RELATIONSHIP

Kemudian dilanjutkan dengan membuat Entity Relation (E-R) model dengan maksud untuk mengetahui hubungan antara masin-masing entity di dalam system. Untuk jelasnya lihat gambar 4.

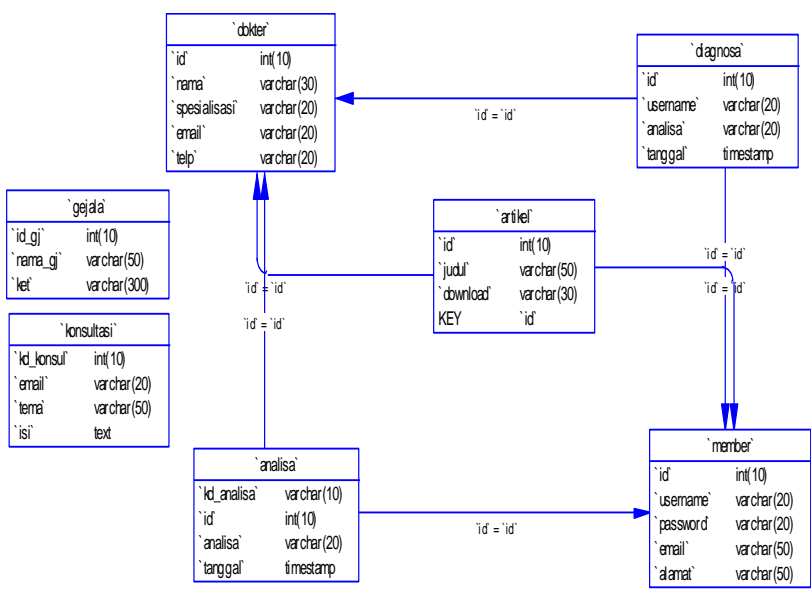

Gambar 4. ER-Model

\section{ALGORITMA CHAINNING}

FOWARD

Forward chaining atau runut maju memiliki arti mempergunakan himpunan kaidah kondisi aksi. Dalam metode ini kaidah interpreter mencocokkan fakta atau statement dalam pangkalan data dengan situasi yang dinyatakan dalam anticendent atau kaidah if. Bila fakta dalam pangkalan data telah sesuai dengan kaidah if maka kaidah distimulasi (lihat gambar 5). Proses ini diulang hingga didapatkan hasil.

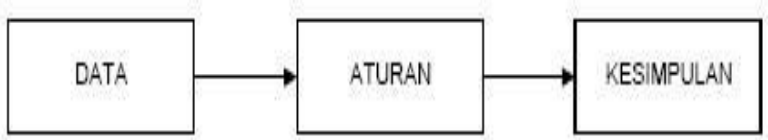

Gambar 5. Kaidah dalam algoritma Foward Channing 


\section{HASIL}
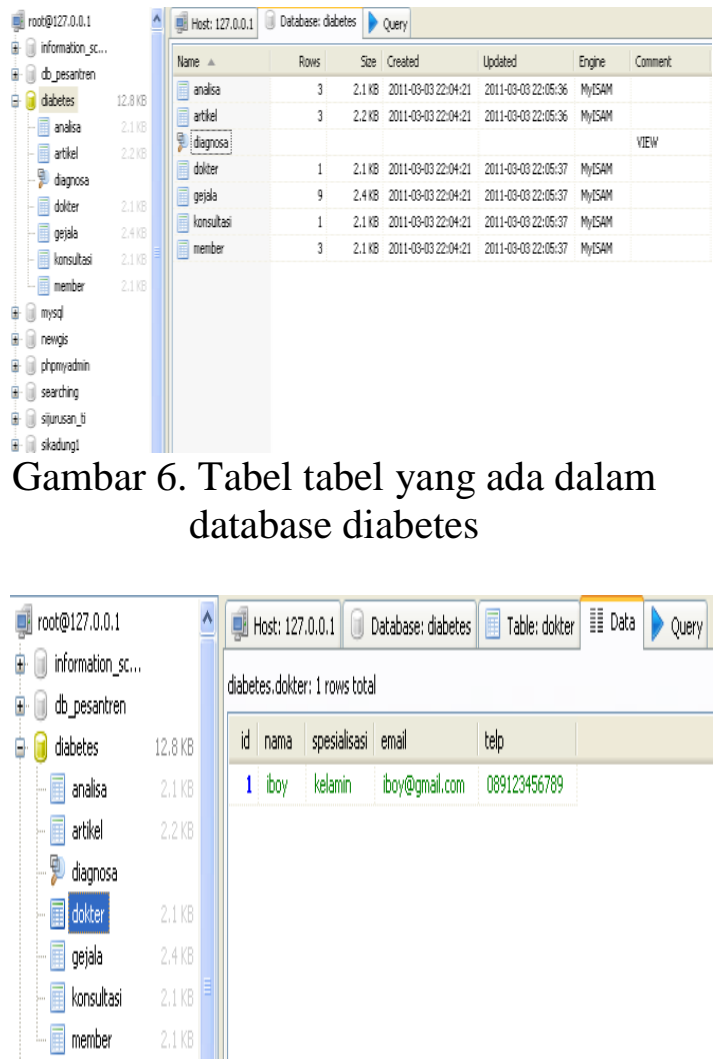

Gambar 7. Field table dokter yang ada di database diabetes

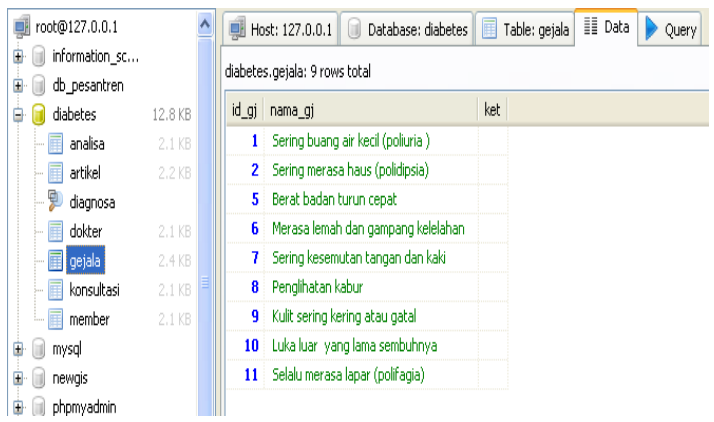

Gambar 8. Field table gejala yang ada di database diabetes

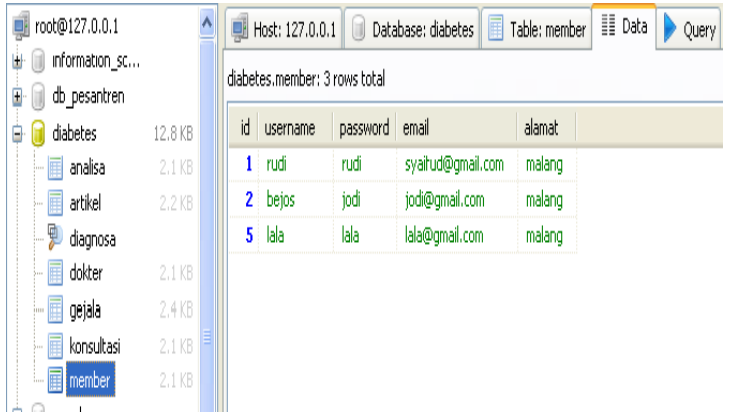

Gambar 9. Field table member yang ada di database diabetes

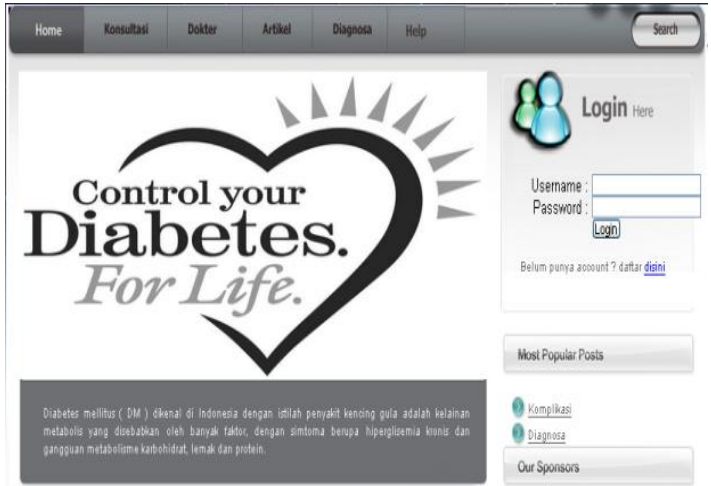

Gambar 10 Layout gambar website system pakar penyakit diabetes militus

\section{KESIMPULAN DAN SARAN KESIMPULAN}

Berdasarkan hasil analisa sistem dapat disimpulkan bahwa :

1. Semakin banyak data yang digunakan oleh sistem pakar maka semakin akurat diagnosa penyakit.

2. Sistem Pakar terbukti hanya bersifat memberikan hasil berupa saran untuk pasien dalam deteksi dini penyakit.

\section{DAFTAR PUSTAKA}

1. Alam, A. M J, 2007, Manajemen DataBase, Jakarta.

2. Anonymous, 2007, Database Client/Server, Jakarta.

3. Arhami, M, 2005,Konsep Dasar Sistem Pakar, Yogyakarta:Andi

4. PHP Manual, 2007 The PHP Documentation Group

5. Kadir,A , 2001, Dasar Pemrograman Web Dinamis Mwnggunakan PHP, yogyakarta, Andi 